\title{
MODEL IMPLEMENTASI KETAHANAN PANGAN KELUARGA MELALUI PEMBERDAYAAN MASYARAKAT MENANAM SAYURAN DENGAN METODE HYDROPONIK DI PERUMAHAN SIMPANG RAYA INDAH
}

\author{
IMPLEMENTATION MODEL OF FAMILY FOOD SECURITY \\ THROUH EMPOWERMENT OF PLANTING VEGETABLES WITH \\ HYDROPONIC METHOD AT PERUMAHAN SIMPANG RAYA \\ INDAH
}

\author{
Sri Langgeng Ratnasari \\ Program Studi Magister Manajemen Universitas Riau Kepulauan \\ Jl. Batu Aji Baru No. 99 Batam 29432 \\ E-mail: sarisucahyo@yahoo.com
}

\begin{abstract}
Abstrak
Ketahan keluarga salah satunya dapat dipenuhi melalui ketahanan pangan, disamping ketahanan sandang (pakaian), dan ketahanan papan (perumahan). Untuk mewujudkan ketahan pangan keluarga salah satunya dapat diimplementasikan melalui cara dengan menanam sayuran dengan metode hydroponik. Hal ini merupakan solusi dari keterbatasan lahan (tanah) sebagai media bertanam, dan juga merupakan salah satu solusi harga sayuran yang cukup mahal di Batam karena harus mendatangkan sayuran dari daerah lain, seperti Padang, Medan, Jambi, dan Lingga. Metode penelitian yang digunakan dalam pengabdian masyarakat ini adalah metode penelitian deskriptif kualitatif, dengan teknik pengumpulan data primer melalui observasi dan wawancara. Teknik analisis dalam pengabdian masyarakt ini menggunakan teknik analisis kualitatif dengan mengumpulkan data, menyajikan data, melakukan verifikasi, dan penarikan kesimpulan. Hasil pengabdian masyarakat ini dapat digunakan sebagai salah satu model ketahanan pangan keluarga melalui pemberdayaan masyarakat, khususnya pada masyarakat dengan lahan terbatas dan di perkotaan seperti di Kota Batam maupun Kota lainnya, dan menjadi solusi yang cepat, mudah, dan hemat biaya.
\end{abstract}

Kata kunci: Ketahanan Pangan, Pemberdayaan Masyarakat, Hydroponik, Sayuran

\section{Abstract}

One of the family resilience can be fulfilled through food security, in addition to clothing (clothing), and resilience (housing). One of the ways to realize family food security can be implemented by planting vegetables using the hydroponic method. This is a solution to the limited land (land) as a planting medium, and is also one of the solutions to the price of vegetables which is quite expensive in Batam because it has to bring vegetables from other regions, such as Padang, Medan, Jambi and Lingga. The research method used in community service is a qualitative descriptive research method, with primary data collection techniques through observation and interviews. The analysis technique in this community service uses qualitative analysis techniques by collecting data, presenting data, conducting verification, and drawing conclusions. The results of community service can be used as a model of family food security through community empowerment, especially for communities with limited land and in urban areas such as Batam City and other cities, and become a solution that is fast, easy, and cost effective.

Keywords: Food Security, Community Empowerment, Hydroponics, Vegetables 


\section{PENDAHULUAN}

Batam adalah kota industri yang didominasi oleh masyarakat urban dari seluruh kota di Indonesia. Batam tidak memiliki area pertanian dan hasil pertanian, baik sayur-sayuran maupun buah-buahan. Kebutuhan sayur-sayuran di Kota Batam diperoleh dari Padang, Medan, Jambi, dan daerah-daerah lain yang dekat dengan Batam, bahkan impor dari Malaysia. Dengan kondisi demikian, maka harga sayur-sayuran di Kota Batam lebih mahal dibandingkan dengan daerah lainnya. Hal ini yang mendorong dilakukannya kegiatan pengabdian masyarakat berupa pemberdayaan masyarakat dalam hal ini keluarga untuk menanam sayur-sayuran dengan metode hydroponik untuk mewujudkan ketahanan pangan keluarga.

Dalam tiga tahun terakhir perkebunan hidroponik bermunculan. Teknologi ini sangat banyak memberikan keuntungan terutama dapat menghemat biaya investasi sekitar 38\%, dan mampu menghasilkan sayuran yang dipersyaratkan pasar (Rahimah, 2012). Perlakuan media tanam yang sesuai membuat tanaman sehat sehingga dapat bertahan dari serangan hama dan penyakit.

Media tanam merupakan salah satu unsur yang paling berperan dalam pertumbuhan tanaman, selain sebagai penopang akar tanaman, ketersediaan unsur hara yang terdapat dalam media tanam sangat dibutuhkan. Dalam budidaya tanaman terutama sayuran media tanaman merupakan faktor penentu berhasil tidaknya suatu budidaya. Selain itu media tanaman juga ikut menentukan kualitas dan kuantitas tanaman yang dihasilkan.

Media tanam yang digunakan sebagai media tumbuh tanaman hidroponik banyak jenisnya. Syarat media tanam hidroponik yaitu dapat dijadikan tempat berpijak tanaman, mampu mengikat air dan unsur hara yang dibutuhkan untuk pertumbuhan tanaman, mempunyai drainase dan aerasi yang baik, dapat mempertahankan kelembaban disekitar akar tanaman, dan tidak mudah lapuk

Keluarga merupakan unit terkecil dari masyarakat yang terdiri atas kepala keluarga dan beberapa orang yang berkumpul dan tinggal di suatu tempat di 
bawah suatu atap dalam keadaan saling ketergantungan, Effendi (2015). Peran keluarga sangat penting bagi keluarga itu sendiri dan masyarakat, oleh karena itu didorong untuk melakukan penanaman sayur-sayuran dengan metode hydroponik di area rumah-masing-masing.

Kegiatan pengabdian masyarakat ini dilakukan di Perumahan Simpang Raya Indah, Kecamatan Batam Kota, Kota Batam. Lokasi perumahan berada di sebelah Perumahan Cendana, sebelum putaran ke kiri arah Bandara Hang Nadim dan ke kanan arah ke Pelabuhan Punggur. Masyarakat di Perumahan Simpang Raya Indah didominasi oleh karyawan sebanyak 90 persen dari 150 Kepala Keluarga, dan sisanya 10 persen adalah wirausaha. Meskipun masyarakat yang berprofesi sebagai karyawan dan wirausaha, sebagian besar diantara mereka memiliki keinginan untuk menanam sayur-sayuran sendiri untuk memenuhi kebutuhan sayur-sayuran keluarganya dan sebagai media rekreasi dan relaksasi bagi keluarga, dan dikarenakan terbatasnya lahan tanah, maka metode hydroponik menjadi pilihan utama.

Metode hydroponik menurut Wijayani (2010) adalah salah satu perkembangan teknologi budidaya pertanian untuk mendukung terciptanya kawasan rumah pangan lestari adalah teknologi hydroponik. Hal ini disebabkan oleh semakin langkanya sumber daya lahan, terutama akibat berkembangnya sector industri dan jasa, sehingga kegiatan usaha pertanian konvensional semakin tidak kompetitif karena tingginya harga lahan.

Menurut Prapanca (2015) bahwa budidaya secara hydroponik adalah budidaya tanaman tanpa menggunakan media tanah. Unsur-unsur hara yang diperlukan tanaman ditambahkan melalui pemberian larutan yang mengandung unsure hara yang dibutuhkan oleh tanaman, sedangkan sistem vertikultur merupakan modifikasi penempatan tanaman secara bertingkat untuk mengurangi penggunaan lahan atau tempat tanaman yang dibudidayakan. Metode hydroponik yang dipilih dengan menggunakan pipa dan botol-botol bekas minuman. 
Hidroponik merupakan salah satu cara bercocok tanam yang memanfaatkan air sebagai media nutrisi yang akan langsung diserap oleh tanaman sebagai penunjang tumbuh tanaman. Hidroponik Bisa dilakukan di lahan terbatas perkotaan, Haryanto, Muthahanas, dan Sarjan (2016).

Sayur merupakan sumber makanan yang mengandung gizi lengkap dan sehat. Sayur berwarna hijau merupakan sumber kaya karoten (provitamin A). Semakin tua warna hijaunya, maka semakin banyak kandungan karotennya. Salah satu sayuran yang sering dikonsumsi oleh masyarakat adalah sawi hijau (Brassica Juncea L). Sawi hijau, dapat dikategorikan kedalam sayuran daun. Sawi, memiliki nilai ekonomis tinggi setelah kubis dan brokoli. Selain itu, tanaman ini juga mengandung mineral, vitamin, protein dan kalori. Oleh karena itu tanaman ini menjadi komoditas sayuran yang cukup populer di Indonesia, Widyasanti, dan Rahmah (2016)

Penerapan pengabdian masyarakat ini membantu masyarakat (keluarga) di Perumahan Simpang Raya Indah, Kecamatan Batam Kota, Kota Batam untuk mengoptimalisasi pemanfaatan sumberdaya pekarangan maupun lahan yang tidak terpakai secara optimal dan lestari dengan aneka tanaman sehingga gizi keluarga sehari-hari terpenuhi dan dapat menjadi sumber pendapatan rumah tangga. Kegiatan pengabdian kepada masyarakat ini bertujuan untuk meningkatkan kepedulian, pengetahuan dan ketrampilan anggota keluarga sebagai peserta kegiatan pengabdian kepada masyarakat untuk menanam sayuran dengan metode hydroponik.

Pengabdian masyarakat ini menggunakan referensi dari hasil pengabdian masyarakat yang telah dilakukan Solihin tahun 2017 tentang hydroponic, Solihin (2017).

\section{METODOLOGI}

Pengabdian masyarakat ini menggunakan metode studi literatur dengan menggunakan analisis kualitatif dan deskriptif, serta metode andragogi. Metode andragogi adalah metode yang menekankan dan menerapkan Program Tindak 
Partisipatif (Partisipatory Action Program) dari keluarga sebagai peserta melalui pelatihan, diskusi, kerja kelompok, dan demonstrasi lapangan (Demplot) pada seluruh kegiatan. Hal ini untuk menguraikan dan menjelaskan keterkaitan pengabdian masyarakat yang terdahulu dengan pengabdian masyarakat pada saat ini, sehingga pengabdian masyarakat terdahulu dapat digunakan sebagai referensi dan melengkapi pengabdian masyarakat yang sekarang.

\section{PEMBAHASAN}

Pelaksanaan pengabdian kepada masyarakat ini sudah terealisasi penuh 100\%. Kegiatan ini merupakan salah satu kegiatan yang mencerminkan ketauladanan pemimpin. Pemimpin adalah sesorang yang mencurahkan tenaga dan pikirannya untuk mempengaruhi oranglain dalam mencapai sebuah tujuan, Lemhannas Republik Indonesia (2016). Kegiatan ini diawali dengan diskusi antara Tim Pelaksana Pengabdian Kepada Masyarakat tentang rencana yang dikerjakan, penentuan lokasi dan persiapan kegiatan yang dilakukan, Panduan Penelitian Dan Pengabdian Kepada Masyarakat Edisi XII, (2018). Pada Bulan 6 Mei 2017 dilakukan survei pertama di lokasi dengan beberapa keluarga di Perumahan Simpang Raya Indah, Kecamatan Batam Kota, Kota Batam. Diskusi berikutnya pada 12 Mei 2017 dengan melibatkan anggota tim sebagai pendamping. Pendamping sebelum melakukan pendampingan diberikan pengarahan tentang kegiatan pengabdian masyarakat yang akan dilaksanakan.

Pada survey kedua 18 Mei 2017 tim pelaksana bersama dengan mahasiswa pendamping mendatangi kelompok keluarga (Dasa Wisma) sebagai mitra untuk mendiskusikan tentang lahan pekarangan yang akan digunakan untuk kegiatan pengabdian kepada masyarakat, dan disepakati bersama waktu pelaksanaan kegiatan pengabdian kepada masyarakat mulai dari jadwal waktu pelatihan dan pelaksanaan demplot bersama anggota kelompok keluarga (Dasa Wisma). Lahan pekarangan yang digunakan untuk kegiatan pengabdian kepada masyarakat ini merupakan lahan pekarangan rumah milik keluarga. 
Persiapan awal yang dilakukan adalah pembuatan kerangka untuk menanam sayuran secara hidroponik dan vertikultur. Konstruksi rak tempat budidaya dikerjakan oleh mitra kelompok tani yang sudah pernah melakukan kegiatan sejenis. Sementara rak-rak tersebut dikerjakan, dilakukan juga penyemaian benih sayuran yang diperkirakan setelah umur 14 hari setelah semai baru kemudian dipindahkan ke tempat pemeliharaan berikutnya. Kegiatan berikutnya adalah pelatihan untuk menyampaikan materi oleh Tim Pelaksana kepada anggota kelompok Dasa Wisma.

Metode yang digunakan adalah pendidikan orang dewasa dengan teknik partisipatif. Materi pelatihan meliputi Pengertian KRPL, hidroponik dan vertikultur; Pengembangan usaha mandiri dan kreatif bagi anggota kelompok Dasa Wisma melalui pemanfaatan pekarangan; Pola kemitraan antara tim pelaksana, kelompok Dasa Wisma dan dunia usaha (mitra usaha), serta dengan perbankan; Pemanfaatan pekarangan untuk skala usaha produktif; Teknik budidaya sayuran sistem hidroponik secara vertikultur; serta Pasca panen dan pemasaran hasil, Surtinah dan Nizar (2017).

Sebelum penyampaian materi dilakukan pre test untuk melihat gambaran seberapa besar kemampuan atau pengetahuan 30 orang anggota peserta yang berkaitan tentang materi yang akan disampaikan. Hasil pre test menunjukkan pengetahuan peserta sangat bervariasi, nilai yang diperoleh mulai yang terendah 30 sampai yang tertinggi 100. Hal ini diduga kemungkinan disebabkan karena faktor tingkat pendidikan anggota peserta yang berbeda.

Secara umum rara-rata nilai yang diperoleh sebesar 75,5 hal ini menunjukkan bahwa ada $15 \%$ peserta mendapatkan nilai di bawah 60 dan $85 \%$ mendapatkan nilai di atas 60 . Hal ini berarti sebagai besar anggota peserta sudah memahami tentang KRPL, pemanfaatan pekarangan maupun tentang hidroponik serta vertikutur. Setelah pre test dilajutkan dengan penyampaian materi pelatihan oleh Tim Pelaksana.

Pada kegiatan pelatihan ini Tim Pelaksana didampingi oleh Nara Sumber yang sudah berpengalaman di bidangnya seperti Bapak Rafi sebagai Wirausaha 
yang mempunyai usaha budidaya sayuran organik dan mempunyai pangsa pasar super market dan hotel.

Selama dalam penyampaian materi para peserta sangat tekun untuk mendengarkan serta menyimak isi materi dan pada sesi diskusi atau tanya jawab sangat antusias, hal ini ditunjukkan dengan materi pertanyaan yang diajukan dan tanggapan balik dari jawaban yang diperoleh. Setelah selesai pelatihan dilanjutkan dengan demplot. Demplot berupa praktik langsung dalam teknik budidaya sayuran secara hidroponik vertikutur. Sambil praktik langsung, dilanjutkan dengan diskusi mulai dari persiapan pembuatan dan kebutuhan nutrisi, sistem kerja hidroponik vertikutur.

Secara keseluruhan pelaksanaan kegiatan pengabdian kepada masyarakat ini menunjukkan bahwa kelompok keluarga (Dasa Wisma) secara antusias sangat mendukung adanya kegiatan pengabdian kepada masyarakat ini. Hal ini didukung oleh sambutan dan penyataan dari Bapak Helmi Ketua RW Perumahan Simpang Raya Indah, Kecamatan Batam Kota, Kota Batam yang ikut mendampingi selama kegiatan berlangsung. Demikian pula tanggapan yang diberikan oleh peserta selama pelatihan dengan adanya pertanyaan-pertanyaan selama sesi diskusi. Penjelasan yang diberikan oleh Tim Pelaksana sebagai nara sumber dapat dimengerti dan dipahami dengan baik, hal ini ditindak lanjuti pada saat Demplot, dapat dipraktikkan secara langsung.

Pada akhir kegiatan pengabdian kepada masyarakat ini masyarakat, dalam hal ini keluarga telah mengetahui cara menanam sayur-sayuran dengan metode hdyroponik untuk mewujudkan ketahanan pangan keluarga.

\section{KESIMPULAN DAN SARAN}

\section{Kesimpulan}

Berdasarkan hasil kegiatan pengabdian pada masyakarat, maka dapat ditarik simpulan sebagai berikut: 
1. Model implementasi ketahanan pangan keluarga melalui pemberdayaan menanam sayuran dengan metode hydroponic di Perumahan Simpang Raya Indah berjalan dengan baik.

2. Dukungan masyarakat terhadap program pengabdian masyarakat sangat baik.

3. Beberapa masyarakat antusias dan mengembangkannya di pekarangan rumah masing-masing menanam sayuran dengan metode hydroponik.

\section{Saran}

Saran yang dapat diberikan dalam pengabdian masyarakat ini adalah sebagai berikut: memberdayakan masyarakat untuk memanfaatkan lahan kosong untuk digunakan menanam sayuran dengan metode hydroponik melalui kelompok dasa wisma. Memberikan penyuluhan dan pelatihan secara berkala, minimum sebulan sekali untuk mengembangkan implementasi kegiatan pengabdian masyarakat yakni menanam sayuran dengan metode hydroponik.

\section{REFERENSI}

Dwiratna, N.P.S., Widyasanti, A., dan Rahmah, D.M. 2016. Pemanfaatan Lahan Pekarangan Dengan Menerapkan Konsep Kawasan Rumah Pangan Lestari. Dharmakarya: Jurnal Aplikasi Iptek Untuk Masyarakat. Vol.5, No.1, Mei 2016.

Effendi. 2015. Manajemen Keluarga. Surabaya: Semesta Anugerah.

Haryanto, Hery, Irwan Muthahanas, dan M. Sarjan. 2016. Pengembangan Kawasan Rumah Pangan Lestari Di Perkotaan Dengan Sistem Hidroponik Vertikultur. Jurnal Abdi Insani Unram. Vol.3, No.2, September 2016.

Kementerian Riset, Teknologi, dan Pendidikan Tinggi. 2018. Panduan Penelitian Dan Pengabdian Kepada Masyarakat Edisi XII. Jakarta: Kemenristekdikti.

M. Aksa, et al. 2016. Rekayasa Media Tanam Pada Sistem Penanaman Hidroponik Untuk Meningkatkan Pertumbuhan Tanaman Sayuran. Jurnal Pendidikan Teknologi Pertanian. Vol. 2 (2016). Hal. 163-168.

Prapanca. 2015. Bertanam Sayuran Organik Di Kebun, Pot dan Polibag. Jakarta: Penebar Swadaya. 
Lemhannas Republik Indonesia. Modul Bidang Studi Kepemimpinan. 2016. Jakarta: Lemhannas RI.

Rahimah, D. S., 2012. Hidroponik Dibawah Langit. TRUBUS. No. 513 Edisi Agustus 2012/XLIII.

Solihin, Muhammad. 2017. Sosialisasi Penanaman Dengan Metode Hydroponik Di Kecamatan Sagulung. Jurnal Minda Baharu. Vol.1, No.1, Desember 2017.

Surtinah dan Rini Nizar. 2017. Pemanfaatan Pekarangan Sempit Dengan Hidroponik Sederhana Di Pekanbaru. Jurnal Pengabdian Kepada Masyarakat. Vol.23, No.2, April 2017.

Wijayani, A. 2010. Budidaya Paprika Secara Hidroponik: Pengaruhnya terhadap serapan nitrogen atau dalam buah. Jurnal Agrivet. Vol.4, No.1, Juli 2010. 